\title{
Integration of informal recycling sector in Brazil and the case of Sorocaba City
}

\author{
Waste Management \& Research \\ 2017, Vol. 35(7) 721-729 \\ (c) The Author(s) 2017 \\ Reprints and permissions: \\ sagepub.co.uk/journalsPermissions.nav \\ DOI: $10.1177 / 0734242 X 17708050$ \\ journals.sagepub.com/home/wmr
} (\$SAGE

\author{
Nathalia Silva de Souza Lima and Sandro Donnini Mancini
}

\begin{abstract}
Catadores are people who collect and sell materials that can be recycled. This activity has been done informally in many countries for years. Recently, a recognition process has begun for the informal recycling sector, with public and private initiatives. In Brazil, catadores started out associating with each other in co-operatives in the 1980s. In 2010, the Solid Waste National Policy was approved, promoting the inclusion of theses co-operatives in the formal waste management system. However, only in 25 out of 5670 Brazilian municipalities have hired co-operatives as Private Service Providers. The integration of the informal sector has contributed with social, economic and environmental benefits; income generation, reduction of poverty and resource preservation are highlights. Although there was a legal progress, there are great challenges for various actors involved. This paper aims to diagnose the informal recycling sector, emphasizing the integration process that has happened in Brazil. For this, a substantial literature review and a case study were conducted, applying the tool 'InteRa' to the case of Sorocaba. The case showed that it is possible to improve the integration of catadores in the formal waste management system. The co-operatives achieve recycling rates of $2 \%$, higher than the official national rate of $1 \%$. However, we estimate that autonomous pickers increase total recycling in Sorocaba to $9 \%$, still short of the $25 \%$ target via source segregation. Therefore, continuing the integration process will benefit both the pickers, and also the municipality through savings on landfill costs.
\end{abstract}

\section{Keywords}

Brazil, developing countries, informal sector, integration, recycling, solid waste management, waste pickers

Received 18th November 2016, accepted 11th April 2017 by Associate Editor Costas Velis.

\section{Introduction}

According to Brazilian democratic constitution, the environment is a public good for which all citizens are responsible (Brasil, 1988). Brazilian environmental legislation is considered one of the best in the world, especially in terms of biodiversity conservation. This cannot be said for waste management. Over the last 50 years, municipal solid waste (MSW) when collected is disposed of to open dumps or landfills, and local authorities do not seem to devote much attention to that matter (FUNASA, 2010).

Waste pickers or just pickers (catadores in Portuguese) are the people who collect materials that have market value on the streets, landfills or even open dumps, in order to sell them to the recycling industry and make a living (GIZ, 2011). This activity has been done informally in many countries for many years and one of the main urban challenges is to integrate it to the formal recycling sector (Scheinberg, 2012; Wilson and Velis, 2014; Wilson et al., 2006).

That is why recently a recognition and organization process has begun, with public and private initiatives (Ezeah et al., 2013; Scheinberg, 2012). In Brazil, pickers started out associating with each other in co-operatives in the 1980 s, but only in 2010 were they formally be included in the formal waste management system through the National Solid Waste Policy (Brasil, 2010; Dias, 2011).
This paper diagnoses the informal recycling sector (IRS) in Brazil, emphasizing the integration process that has been happening, by presenting the history and background of this integration, its economic, social and environmental benefits and current barriers. Furthermore, using Sorocaba city as a case study, an analysis of the IRS integration at municipal level in two different periods was conducted in order to provide recommendations for the next steps.

\section{Literature review of IRS in Brazil}

\section{History of IRS integration}

Since 1895, waste picking has been reported in urban cities such as Rio de Janeiro and São Paulo (Eingeheer, 2009). It was the only possible income for survival for people that would select materials that could be sold at very low prices to recycling intermediate actors (Lopes, 2006). Local authorities had a very

São Paulo State University, Brazil

\section{Corresponding author:}

Nathalia Silva de Souza Lima, São Paulo State University, Avenida Três de Março, 511, 18087180, Sorocaba - SP, Brazil.

Email: nathslimalahotmail.com 
low view of pickers and police officers would treat them with violence (Lindeman, 2012).

The first organizations of pickers originated when many of them had to compete for materials, so they decided which streets and what materials each person would focus on (Spinosa, 2012). In 1986, the first co-operative for paper collection was created in São Paulo and another was created for paper, plastics and metals collection in 1989 (Spinosa, 2012). In the 1990s, co-operatives were organized with the help of various civil society organizations in Belo Horizonte, Curitiba and Porto Alegre, some of the main cities in Brazil (Lindeman, 2012; Lopes, 2006).

A co-operative is an organization of minimum 20 people who share income and make decisions democratically (Brasil, 1971). The pickers then started networking, and in 1999 the National Movement of Pickers (MNCR, in Portuguese) was created, becoming official in 2001 with the First National Pickers' Congress (Grimberg, 2007; Spinosa, 2012).

Throughout the 2000s, social awareness in general increased in the Brazilian society with the establishment of many social movements, and gaining attention from the public sector. For the first time in 2002, the Brazilian Work Ministry recognized recyclable materials' picking as a profession, which marked the beginning of the integration process of the informal recycling sector in Brazil. In 2006, recyclable materials generated in all public buildings had to be sent to co-operatives of pickers by federal decree, in order to help generate income (INSEA, 2013; Spinosa, 2012).

In 2007, the National Sanitation Policy allowed municipalities to send recyclable materials from municipal solid waste collection to co-operatives of pickers, hiring them as Private Service Providers without the necessity of going through a public bidding process (Brasil, 2007). However, only after the National Solid Waste Policy and its decree were approved in 2010, municipalities were encouraged to legitimize organizations of pickers that could provide the services of collection, sorting and commercialization of recyclable materials to either public or private waste generators (Jacobi and Besen, 2011).

Although there has been a legal progress for the integration of the IRS in Brazil and access to recyclable materials has increased over the years, the sector is still dependent on the value chain for its main source of income. The main actors of the recycling value chain are autonomous pickers, co-operatives of pickers, intermediate companies (accumulate materials in larger lots) and the recycling industry (Franceschini et al., 2010).

The Brazilian government has not regulated the relations between these actors and there are no fiscal or financial incentives for recycling yet. Some studies have found that the recycling trade can be unfair for pickers, autonomous and within co-operatives, who are the most vulnerable actors in the chain (AVINA, 2008; Furlan, 2007; Pinheiro et al., 2014). That is why co-operatives are starting to unite in regional networks, taking up the role of accumulating materials to sell directly to the recycling industry, bypassing intermediate actors (Pinheiro et al., 2014; Rutkowski and Rutkowski, 2015).

\section{Situation of IRS today}

Even though there are no official records, it is estimated that up to 1 million people in Brazil work as pickers, of whom $10 \%$ work at co-operatives and the other $90 \%$ still collect recyclable materials on cities' streets or open dumps (CEMPRE, 2014; Pinheiro Pedro et al., 2012). According to Furlan (2007) and the government report on solid waste management (SNIS, 2014), in smaller cities, a higher proportion of pickers are organized, and those organizations are better integrated with the formal municipal waste management system.

Table 1 presents general characteristics of pickers in Brazil, from three different studies conducted at different times and periods, but uniting important aspects. The 'typical' picker in Brazil is male, of active working age, of African descent and living in an urban area. The average income of pickers who work at co-operatives is more than double the average income of autonomous pickers. One out of five are illiterate and one out of 10 did not finish secondary school. Most of them have access to electricity but only $17 \%$ have computers.

\section{Benefits of integration of IRS}

Most pickers still work independently, many times in bad conditions, risking their health and vulnerable to exploitation by the recycling industry. Hence, formalizing these workers has brought social, economic and environmental benefits (IPEA, 2010). Table 2 presents the social, economic and environmental benefits of integrating these workers in formal value and service chains of recycling.

Besides benefits for the workers, there are benefits for the local authorities, especially economic ones, when less recyclable waste has to be transported and landfilled (Rutkowski et al., 2013; Rutkowski and Rutkowski, 2015; Simões, 2012).

Among environmental benefits, preservation of natural resources is the highlight, as waste pickers collaborate for the circular economy, avoiding contamination of soil, groundwater, and greenhouse gas emissions (Simões, 2012).

\section{Barriers for integration of IRS}

The main barriers concerning the integration of the IRS in Brazil are organizational challenges in co-operatives, recycling market characteristics, public sector dependency and low participation from society.

Most co-operatives lack social, technical and financial bases to offer services of collection, transport and sorting of recyclable materials and there is difficulty in reaching $100 \%$ of urban areas. In different parts of the country, experiences are different from each other and are in different stages, depending on the relationship with the public sector, technical capacity, management, infrastructure and industrialization in the region (INSEA, 2013).

Many autonomous pickers find it difficult to work with other people in co-operatives, which hinders their organization. Communication with public and private sectors, intermediate companies, non-government organizations (NGOs) and general 
Table 1. General characteristics of pickers in Brazil.

\begin{tabular}{|c|c|c|c|}
\hline Category & Indicators & Brazil & Reference \\
\hline \multirow[t]{5}{*}{ Social } & Number of pickers & Between 387,910 and 800,000 & IPEA (2013); MNCR (2008) \\
\hline & Average age (years old) & 39 & IPEA (2013) \\
\hline & Women $(\%)$ & 31 & IPEA (2013) \\
\hline & African descendants $(\%)$ & 66 & IPEA (2013) \\
\hline & Urban residents (\%) & 93 & IPEA (2013) \\
\hline \multirow[t]{2}{*}{ Income } & $\begin{array}{l}\text { Average monthly income per picker at } \\
\text { co-operatives (US\$/month) }\end{array}$ & US\$ 130 & $\begin{array}{l}\text { Programa Catação and } \\
\text { Instituto Walmart (2013) }\end{array}$ \\
\hline & $\begin{array}{l}\text { Average monthly income per } \\
\text { autonomous picker (US } \$ / \text { month) }\end{array}$ & US\$ 38 to US\$ 88 & $\begin{array}{l}\text { Programa Catação and } \\
\text { Instituto Walmart (2013) }\end{array}$ \\
\hline \multirow[t]{3}{*}{ Education } & Illiteracy rate $(\%)$ & 20.5 & IPEA (2013) \\
\hline & $\begin{array}{l}\text { Adults with completed primary school } \\
(\%)\end{array}$ & 24.6 & IPEA (2013) \\
\hline & $\begin{array}{l}\text { Adults with completed secondary } \\
\text { school }(\%)\end{array}$ & 11.4 & IPEA (2013) \\
\hline \multirow[t]{3}{*}{ Access to public services } & $\begin{array}{l}\text { Pickers whose children (0-3 years- } \\
\text { old) go to day care }(\%)\end{array}$ & 22.7 & IPEA (2013) \\
\hline & Electricity at home $(\%)$ & 99 & IPEA (2013) \\
\hline & Sewage collection service at home $(\%)$ & 49.8 & IPEA (2013) \\
\hline Digital Inclusion & Pickers who have computers (\%) & 17.7 & IPEA (2013) \\
\hline
\end{tabular}

Table 2. Benefits of integration of informal recycling chain.

\begin{tabular}{lll}
\hline Social benefits & Economic benefits & Environmental benefits \\
\hline $\begin{array}{l}\text { Improvement in pickers' health } \\
\text { Improvement of working conditions }\end{array}$ & $\begin{array}{l}\text { More stable income } \\
\text { Public sector's savings with waste } \\
\text { management } \\
\text { Utilization of abandoned areas for } \\
\text { sorting facilities } \\
\text { Direct commercialization to } \\
\text { recycling industry }\end{array}$ & $\begin{array}{l}\text { Increase in population's awareness } \\
\text { Preservation of natural resources } \\
\text { (close the loop) } \\
\text { Increase in landfills' capacity }\end{array}$ \\
Human rights & & Increase in urban cleaning \\
Social development & & \\
Increase in self-trust & & \\
Representation before public authorities & & \\
Inclusion of women & & \\
\hline
\end{tabular}

Sources: Spinosa (2012); CEMPRE (2014); Franceschini et al. (2010); Rutkowski et al. (2013); Simões (2012); Besen (2008).

society is another challenge (Besen, 2008; INSEA, 2013; Programa Catação \& Instituto Walmart, 2013; Rutkowski et al., 2013).

The local recycling market in Brazil is still unstable and small; there are few companies and most are informal, because there are no regulations from the national government and it depends on global prices and equipment costs are high (Rede Nossa São Paulo, 2013; Wilson \& Velis, 2014). In addition, fiscal and economic incentives are practically non-existent for recyclable products or recycling industry (Assunção, 2013).

The Solid Waste National Policy gave municipalities two years to create a Plan for Waste Management (Spinosa, 2012). However, in 2013 - three years after the Policy - only 33.5\% of Brazilian municipalities had submitted their plans (IBGE, 2013b). This shows how difficult it has been for the public sector at municipal level to implement the National Policy.

Abramovay et al. (2013) point out that waste management by the public sector at municipal level is marked by corruption, with directed interests for hiring service companies. The authors also state that the political cycles are barriers, because every four years, projects end and programmes are interrupted, thus resulting in inefficiency of actions.

Even though since 2007 it has been possible to hire cooperatives as waste managers, only 11 out of 5,670 municipalities had done so by 2013 (Rutkowski et al., 2013) and 25 by 2015 (Rutkowski and Rutkowski, 2015). Apart from these, most municipalities assist co-operatives by paying basic bills (rent, electricity, water, telephone) and maintenance of machinery and equipment (Furlan, 2007; Marques, 2013).

The National Policy instituted waste segregation at source, which requires society to change its behaviour. This makes environmental education essential for the success of recycling and circular economy. In Brazil, awareness has been raised concerning the possibilities of income generation from waste for catadores and the importance of contribution from every citizen by separating their waste at source, to ensure the quality of recyclable materials collected, which affects directly the value chain (Lükte, 2013; Spinosa, 2012). 


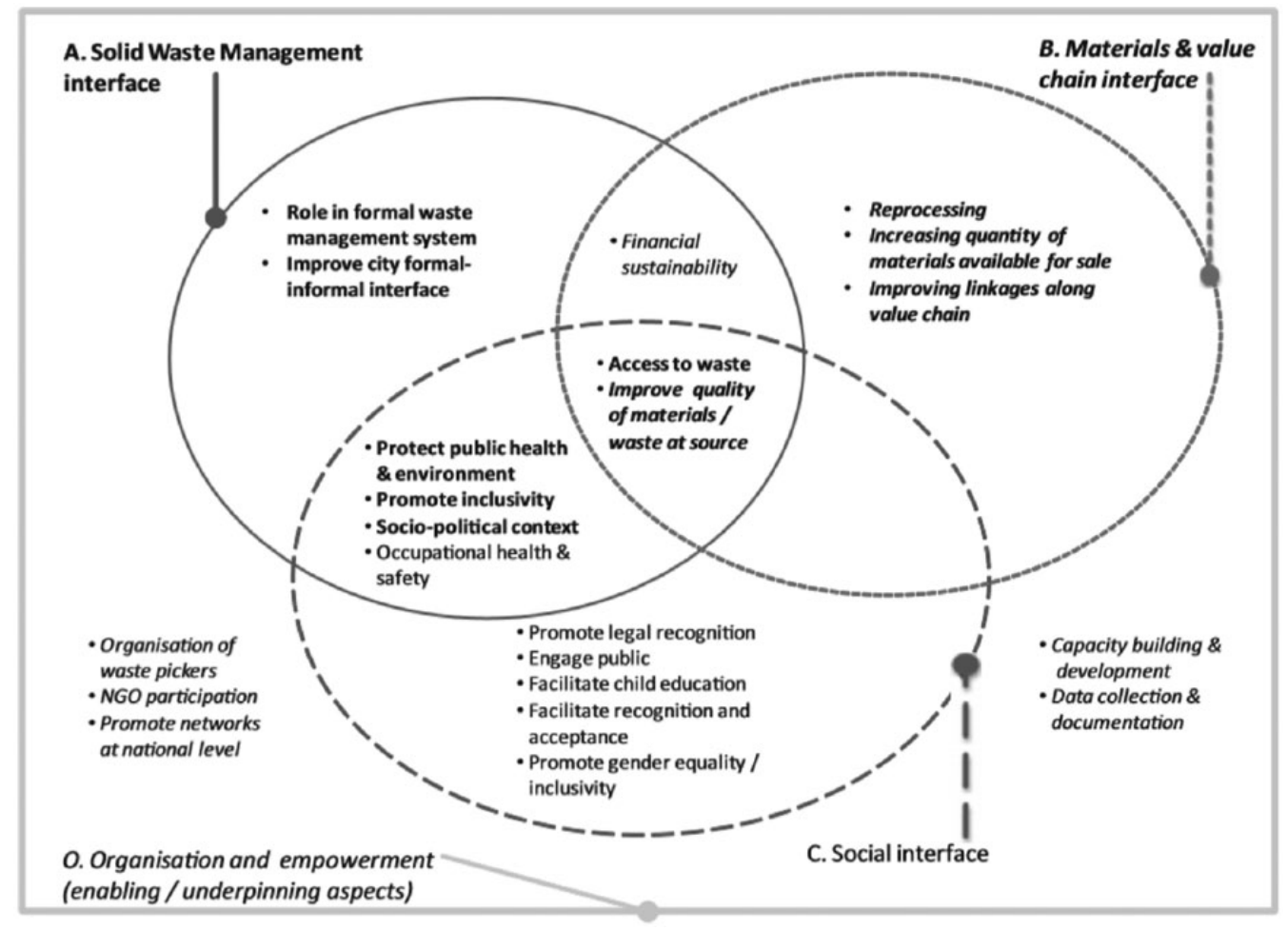

Figure 1. Analytical framework from 'InteRa'. Source: Velis et al. (2012).

With all this in view, recycling rates achieved are officially estimated to be relatively low in Brazil - around $1 \%$ of MSW nationally (SNIS, 2014) - which will be further discussed in the case study.

\section{Methods}

To describe the process of the informal recycling sector integration at national level and identify its main benefits and barriers, a literature review, with government documents, scientific publications and reports from private sector projects was made.

To measure the integration of the informal recycling sector at municipal level, the tool 'InteRa' (Velis et al., 2012) was applied to Sorocaba city, in two different periods: one in 2012 and another in 2015. The data for this case study were collected by analysing municipal documents, scientific articles, field visits and interviews with local pickers who are part of two co-operatives of pickers.

The tool 'InteRa' from Velis et al. (2012) evaluates a set of actions to integrate the informal sector in four categories: Solid Waste Management System, Materials and Value Chain, Social Aspects, Organization and Empowerment. Within each category, there are groups of similar actions and individual points of intervention. The Venn diagram in Figure 1 identifies the groups of actions within the categories which are interdependent. The category organization and empowerment of informal recyclers is called the enabling category by the authors and underpins the other three. To apply the tool, possible interventions are listed and scores allocated according to the local reality. Each category in the end receives an average score from 0.0 to 1.0 , which is plotted on a four-sided radar diagram that allows visual comparisons to other cases.

\section{Case study: Integration of IRS in Sorocaba City}

Sorocaba is located in Southeast of Brazil; it has 630,000 inhabitants of whom 99\% live in urbanized areas (IBGE, 2010, 2013a). Urban waste management is carried out by companies who are hired by the municipality (PMS \& SHS, 2014). Daily, around 530 tons of waste are collected and sent to a sanitary landfill, with an average cost of R\$182/ton (US\$ 50/ton) to collect and transport and R\$ 83/ton (US\$ 23) to landfill it (Mancini, 2015; PMS \& SHS, 2014; SANEX, 2011).

In 2014, the Waste Management Plan of Sorocaba estimated that collection for recyclable materials reached $16 \%$ of the city's population. A monthly average quantity of 330 tons were sent to co-operatives of catadores, equivalent to $2 \%$ of total urban waste. The Plan also estimated that $80 \%$ of all urban waste is recyclable, if biodegradable waste is included (PMS \& SHS, 2014).

Simões et al. (2011) estimated that 1000 pickers worked individually and informally in the streets since the 1990 s, when entrance at the sanitary landfill was prohibited. The first co-operative of pickers was created in 1999, with support from a local NGO and a religious group, but no support from the municipality (Programa Catação \& Instituto Walmart, 2013; Simões et al., 2011).

In 2001, a network of co-operatives from 21 cities nearby Sorocaba was created, in order to improve materials' prices and exchange experiences. This network has 18 co-operatives, from which only one is located in Sorocaba city, and has received 


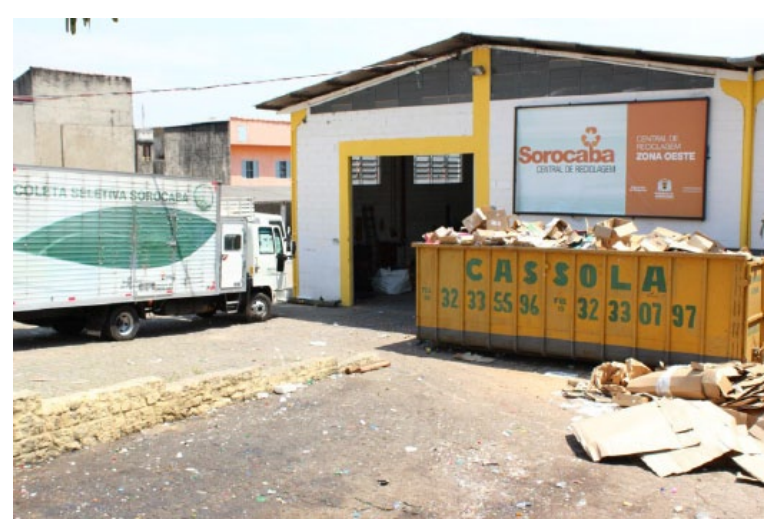

Figure 2. Sorocaba Recycling Centre, a warehouse shared by three co-operatives of pickers.

investments from Petrobrás (Brazilian oil company) for trucks, uniforms, training and computers (Programa Catação \& Instituto Walmart, 2013; Simões et al., 2011).

Only in 2006, the municipality of Sorocaba formalized a partnership with this co-operative and supported the establishment of three new ones, creating a programme for the collection of recyclable materials in the city. During the next two years, the municipality provided a series of trainings to all workers of the four co-operatives located in Sorocaba, and in 2009 collection was entirely mechanized through trucks (Simões et al., 2011).

Support and investments from NGOs and the private sector for co-operatives included financial donations for machinery, equipment and construction and managerial and operational assistance, but have been casual and usually part of social responsibility programmes (Programa Catação \& Instituto Walmart, 2013).

\section{Results and discussion}

\section{Co-operatives of Sorocaba City in 2012}

Each co-operative had its own operation system of residential registration, door-to-door collection, sorting and commercialization. A collection schedule was elaborated and each house received bags to separate the recyclable portion of waste. The municipality allowed the co-operatives to use five warehouses, where more than 30 types of recyclable materials were sorted manually, with provided uniforms and personal protective equipment. Four warehouses were managed by the bigger co-operative and the fifth was occupied by the three other. One of the main challenges co-operatives faced was the lack of managerial, financial and operational abilities because many pickers did not finish a high school level education. For that reason, the University of Sorocaba funded two trainees to do office work at the co-operatives every year (Mantovani et al., 2016; PMS \& SHS, 2014; Programa Catação \& Instituto Walmart, 2013; SANEX, 2011; Simões et al., 2011; Simões, 2012). Figure 2 shows one of the warehouses where three co-operatives of pickers shared space, which was called Sorocaba Recycling Centre.

In May 2012, a Municipal Environmental Policy was approved and selective collection for recyclables was universalized with inclusion of pickers in Sorocaba. Also, 300 autonomous pickers were included in co-operatives (Viana, 2012).

It is important to state that, in Sorocaba, besides those four co-operatives focusing on packaging waste, there are three others which are specialized in other types of waste, such as e-waste and construction and demolition waste (Simões, 2012).

\section{Co-operatives of Sorocaba City in 2015}

A diagnosis for the Municipal Plan for Recyclable Materials Selective Collection of Sorocaba was made in 2015 by a hired consulting firm (PMS \& DRZ, 2015), describing the co-operatives, other stakeholders of recycling chain, such as intermediate actors and autonomous pickers. Table 3 shows indicators for the co-operatives' progress from 2008 to 2015.

Progress has been made by co-operatives from 2008 to 2012: the quantity of materials collected has increased, as well as income and productivity per person. This is because of increasing investment from public and private sectors in training and equipment, indicating gradual integration of pickers in the formal waste management system.

If quantities of materials collected are compared through time, from 2008 to 2012, quantities increased significantly, by an average of $80 \%$ every two years. However, from 2012 to 2015, a three-year interval, the quantity increased only by $10 \%$. This is probably due to the stagnation in number of collection points and investments for the co-operatives, which were already operating in full capacity in 2012. Th number of workers at co-operatives grew until 2012, declining from 2012 to 2015, which did not affect the monthly productivity per person, a variable that has only improved through time, from 1.76 tons per person in 2008 to 2.73 tons per person in 2015 , an increase of $55 \%$.

The municipality of Sorocaba estimates that there are 1250 autonomous pickers. Of interviewed pickers, $86 \%$ had never been associated with a co-operative, due to ignorance of their existence, not agreeing with their organizational structure, routine or lower pay. Pickers, who did work at co-operatives before, declared to have left because of low and delayed payments (PMS \& DRZ, 2015). As shown in Tables 1 and 2, payments for workers in cooperatives are higher and more secure, however co-operatives pay 
Table 3. Progress archived by co-operatives of pickers in Sorocaba from 2008 to 2015.

\begin{tabular}{|c|c|c|c|c|}
\hline Indicators & 2008 & 2010 & 2012 & 2015 \\
\hline Quantity of recyclable materials (tons/month) & 99 & 185 & 333 & 367 \\
\hline Quantity of recyclable materials (tons/year) & 1185 & 2221 & 4000 & 4400 \\
\hline Recycling rate (quantity of recyclable materials collected/total quantity of MSW) & $0.8 \%$ & $1.5 \%$ & $2.6 \%$ & $1.7 \%$ \\
\hline Workers in co-operatives & 56 & 95 & 160 & 134 \\
\hline Average monthly income per person (US\$ per montha) & 106 & 192 & 232 & 321 \\
\hline Average monthly productivity (tons per person) & 1.76 & 1.95 & 2.08 & 2.73 \\
\hline
\end{tabular}

aUS\$ 1 = R\$ 3.58 (1 June 2016).

Sources: PMS \& SHS (2014); PMS \& DRZ (2015); CETESB (2008); CETESB (2010); CETESB (2012); CETESB (2015).

taxes and workers are paid weekly or monthly, which can give autonomous pickers the impression of lower and delayed payments, when usually they receive daily 'cash in hand' payments.

Most of them work in bad conditions with no protection equipment, exposed to the weather, urban noise and risks of accidents. $64 \%$ said that intermediate informal companies charged them to use the carts to collect the materials. Most pickers accumulated materials in their own houses, exposed to weather and bringing public health risks (PMS \& DRZ, 2015). Even with incentives from the Solid Waste National Policy and municipal efforts, most pickers prefer to work on the streets, choosing their hours and having a daily basis payment.

If it is assumed that these autonomous pickers are half as efficient as pickers from co-operatives because they have less access to infrastructure, it is possible to estimate based on MSW quantity in 2015 (CETESB, 2015) that autonomous pickers are accountable for an additional $7 \%$ to the recycling rate in Sorocaba, which makes a total of $9 \%$ recycling rate, when added to numbers from the co-operatives.

The most valuable materials are PET bottles and aluminium cans and a "silent agreement" between pickers and intermediate actors define who will pick what and where. In Sorocaba city, intermediate companies who commercialise up to 100 tons a month are considered to be informal. The city was recommended to approach these companies, but it is not clear how they will be formalised as the Municipal Plan for Selective Collection for Recyclable Materials is not finished yet (PMS \& DRZ, 2015).

\section{'InteRa' for Sorocaba city}

Figure 3 presents results of application of 'InteRa' for Sorocaba in 2012 and 2015.

As shown in the figure, in a three-year period, there was a slight improvement in the integration of the informal recycling sector in Sorocaba in all four categories. The integration actions that most evolved were that even though the number of pickers at co-operatives decreased, they reported to have included autonomous pickers in this period; utilization of personal protection equipment increased as did participation of co-operatives in decision making for the municipal waste management plan.

Most progress was made in the Waste Management interface, from 0.58 to 0.72 , marked by the beginning of elaboration of a Municipal Plan for Recyclable Materials Selective Collection with inclusion of co-operatives' services, a rare instrument of municipal waste management in Brazil. Many informal recycling actors were recognized in the diagnosis part of the plan, rarely acknowledged by local authorities in Brazil, such as autonomous pickers and intermediate smaller companies and junkshops. However, recyclable material collection is only available to $16 \%$ of population of Sorocaba and it has not been expanded since 2012.

In the Social interface that improved from 0.59 to 0.65 , scholarships for pickers started to be offered by the University of Sorocaba, the local private university, showing the beginning of opportunities for professionalization. They have been granted to study Management, Environmental Management or Environmental Engineering. This can help them to improve as an organization and to legalize their activities. There is also opportunity to increase the public engagement by promoting source separation, already done by the co-operatives while educating people and companies as collection points for recyclable waste. Another improvement point is to include women in decision making; in 2015, they only had operational coordination roles, and most leading managerial positions were held by men.

The improvement in the Materials and Value Chain interface, from 0.52 to 0.56 , shows the recognition of intermediate companies and integration efforts in the Municipal Plan for Recyclable Materials Selective Collection. Some of the opportunities for improvement are setting up contracts with waste generators, using wheeled containers for collection and expanding the range of materials recycled.

The Organization and Empowerment interface, improved from a score of 0.45 to 0.49 , but was the lowest of all interfaces in both years. In general, co-operatives in Brazil are vulnerable to market prices of materials, with no other income from services, for example. They depend on material donations and support from many entities such as public sector, NGOs and support from universities. In addition, investments in co-operatives' infrastructure have not grown, which stagnated the coverage of the selective collection programme, as well as the quantity of recyclable materials collected, that had only 10\% increase from 2012 to 2015, as mentioned before.

\section{Recommendations to Sorocaba}

The Municipal Plan for Recyclable Materials Selective Collection has been under development and targets are of recycling all 


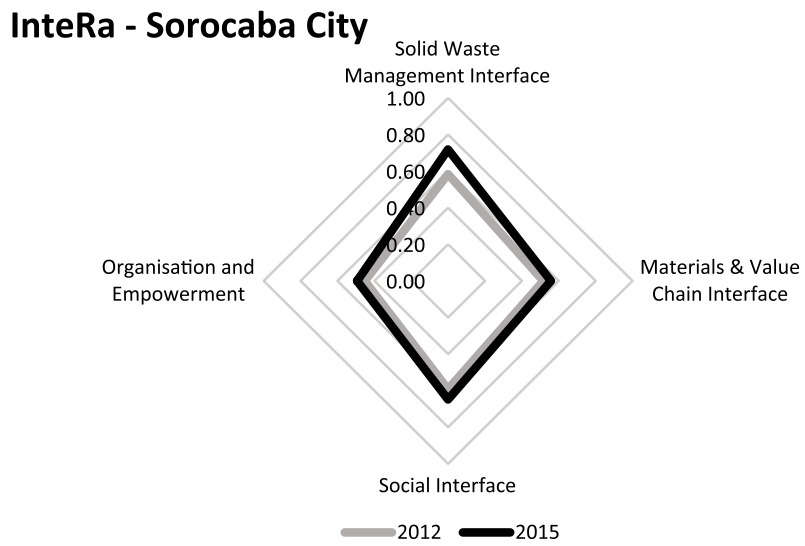

Figure 3. 'InteRa' for Sorocaba in 2012 and 2015.

materials that are potentially recyclable by 2035 , equivalent to about eight thousand tons a month (DRZ, 2015). This would result in an estimated $25 \%$ recycling rate from MSW, considering an increase in MSW generation of $145 \%$ in 20 years.

In order to achieve maximum recycling (only for dry recyclables, excluding compostable waste) in Sorocaba, greater investments in infrastructure of co-operatives (managerial, financial and operational) and education for pickers and to engage the general public are needed. This could come from partnerships with public and private sectors. Furthermore, the local authorities provide support by paying bills, machinery, equipment and trucks, but continue to resist paying for the services provided by co-operatives to society.

It is valuable to point out the responsibility of the larger generators of urban waste, such as commercial buildings, who can direct their recyclable materials to co-operatives, while paying for services provided with a formal contract. In Sorocaba, cooperatives depend on material donations made by some commercial partners and mostly residential collaborators.

A systematic approach by local authorities regarding the informal recycling chain in Sorocaba is needed. The activities carried out by intermediate actors (companies and individuals) should be regulated, avoiding exploitation of pickers. There are several opportunities for the creation of new business models that could be promoted by a municipal policy in order to formalize the whole sector, creating jobs and income to at least 1250 pickers who work in the city.

Some co-operatives in Belo Horizonte have cart pickers who collect on the street as a regular associate who earns money based on how much materials they collect (Rutkowski and Rutkowski, 2015). Another option could be to register autonomous waste pickers as micro enterprises in order to provide collection services to the junkshops, who should pay for services as well, not only for materials. Yet another option is to formalize these intermediate companies and hire autonomous pickers as employees that collect the waste on the streets, providing all equipment needed. This would require the city to pay these intermediate companies for services to society as well; however, this is unlikely to happen in practise. The Solid Waste National Policy in this point limits these opportunities and prioritises the co-operative business model for waste pickers.

\section{Conclusion}

The work of pickers is very important to Brazilian cities, although public participation is still low. The integration of the informal recycling sector contributes with social, economic and environmental benefits. The inclusion of waste pickers in the formal labour system contributes to income generation, poverty reduction and preservation of natural resources.

The Brazilian authorities have acted in order to formalize pickers and include them in society. However, it has been done slowly and by bottom-up pressure from pickers. 'Recyclable materials' collector' was legally recognized as an occupation and several co-operatives and associations were formed to provide collection, sorting and commercialization of recyclable materials.

Urban waste recycling rates in Brazil are relatively low, with an official national figure of just $1 \%$ (SNIS, 2014). In Sorocaba city, the co-operatives achieve a rate of $2 \%$, but we estimate that the total recycling, allowing also for less efficient separation for recycling by the larger number of autonomous pickers, is $9 \%$. This suggests that the official national recycling rate ignores the activities of independent pickers, and is thus a gross under estimate. The Municipal Plan for Recyclable Materials Selective Collection from Sorocaba targets a recycling rate of $25 \%$. Starting from a baseline of $9 \%$ rather than $2 \%$, coupled with potential productivity improvements for the autonomous pickers through a renewed effort towards their inclusion, and improvements for all pickers through the extension of selective collection, makes this target much more achievable.

Despite the progress already made in the legal recognition of pickers, achieving a $25 \%$ recycling target in practice will still present great challenges for the various stakeholders. For co-operatives, the challenges include to integrate infrastructure, professionalization and external communication that affects their managerial sustainability, to reduce their dependency on other actors, such as municipalities, and to recruit autonomous pickers, 
by creating incentives to grow the proportion of organised waste pickers from $10 \%$ to an initial target of $50 \%$ and eventually towards $100 \%$. One way to mitigate their dependency is for co-operatives to be hired as Private Service Providers and be paid for through collecting, sorting and providing a sound waste management.

For the public sector, the main challenge is to hire co-operatives all over Brazil; even though it might look like this will increase their costs by hiring more service providers, actually, increasing recycling rates mean reducing quantities and costs associated with regular collection and landfilling. Other challenges include to coordinate holistically the integration of informal actors of the recycling chain, because some are still being ignored by public policies; to implement financial incentives to recycling; to monitor results with trustworthy data collection and to build capacity within public employees, concerning waste management service.

For the private sector and packaging producers, that have reacted in a fairly leisurely manner through pilot projects of reverse logistics of products and single investments in co-operatives, the challenge is to take part in the shared responsibility imposed by the Solid Waste National Policy to ensure that post-consumer packaging and products reach the adequate destination, including paying the costs of infrastructure, education and logistics in general.

Lastly, for the population, that has a fundamental role so that public policies are implemented successfully, the challenge is to collaborate by segregating its waste and directing it correctly to recycling programmes.

The 'InteRa' tool proved to be a very efficient tool to analyse integration efforts in a particular city and the results can be compared to other cases. The case study of Sorocaba has portrayed an example of an urban city from Brazil and its efforts in integrating organized waste pickers into the formal waste management system. The way forward is to implement the Municipal Plan for Recyclable Materials Selective Collection, including measures to overcome these challenges holistically and continue the process of integration of pickers.

\section{Acknowledgments}

Special thanks go to Maria Tsakona and Costas Velis from D-Waste, Professor Sandro Donnini Mancini, Professor Luiza Amália Pinto Cantão, Michel Xocaira Paes and Veridiana Silveira Rodero from São Paulo State University for their contributions to this research.

\section{Declaration of conflicting interests}

The authors declared no potential conflicts of interest with respect to the research, authorship, and/or publication of this article.

\section{Funding}

The authors disclosed receipt of the following financial support for the research, authorship, and/or publication of this article: This work was partly supported by D-Waste.

\section{References}

Abramovay R, Speranza JS and Petitgand C (2013) Lixo Zero: Gestão de Resíduos Sólidos para uma sociedade mais próspera. Sao Paulo, Brazil: Planeta Sustentável.
Assunção A (2013) Se metade das prefeituras de SP implantasse a coleta seletiva, indústria de reciclagem não conseguiria absorver resíduos, diz promotor na Fiesp. Agência Indusnet Fiesp, 27 ago. 2013.

AVINA (2008) Reciclaje sustentable y solidario. Available at: http://avina. net/esp/wp-content/uploads/2011/11/rec.pdf (accessed 30 July 2015).

Besen GR (2008) Sustentabilidade dos Programas de Coleta Seletiva com Inclusão Social: Avanços, Desafios e Indicadores. In: Proceedings of the IV Encontro Nacional da Anppas, Brasilia, Brazil, 4-6 June, pp.1-14.

Brasil (1971) Law 5,764 from December 16th of 1971. National Co-operatives' Policy (Política Nacional de Cooperativismo).

Brasil (1988) Constitution. Brasília, Brazil: Senate House.

Brasil (2007) Law 11,455 from January 5th of 2007. National Sanitation Policy.

Brasil (2010) Law 12,305 from August 2nd of 2010. National Solid Waste Policy.

CEMPRE (Compromisso Empresarial Para Reciclagem) (2014) Guia Coleta Seletiva de Lixo. São Paulo, Brazil: CEMPRE, 30 pages.

CETESB (Companhia Ambiental do Estado de São Paulo) (Environmental Company of São Paulo State) (2008) Inventário Estadual de Resíduos Sólidos Domiciliares 2008 (State Report of Household Solid Waste 2008). Available at: http://residuossolidos.cetesb.sp.gov.br/residuos-solidos/residuos-urbanos-saude-construcao-civil/publicacoes-e-relatorios/ (accessed 3 February 2017).

CETESB (Companhia Ambiental do Estado de São Paulo) (Environmental Company of São Paulo State) (2010) Inventário Estadual de Resíduos Sólidos Domiciliares 2010 (State Report of Household Solid Waste 2010). Available at: http://residuossolidos.cetesb.sp.gov.br/residuos-solidos/residuos-urbanos-saude-construcao-civil/publicacoes-e-relatorios/ (accessed 3 February 2017).

CETESB (Companhia Ambiental do Estado de São Paulo) (Environmental Company of São Paulo State) (2012) Inventário Estadual de Resíduos Sólidos Domiciliares 2012 (State Report of Household Solid Waste 2012). Available at: http://residuossolidos.cetesb.sp.gov.br/residuos-solidos/residuos-urbanos-saude-construcao-civil/publicacoes-e-relatorios/ (accessed 3 February 2017).

CETESB (Companhia Ambiental do Estado de São Paulo) (Environmental Company of São Paulo State) (2015) Inventário Estadual de Resíduos Sólidos Domiciliares 2015 (State Report of Household Solid Waste 2015). Available at: http://residuossolidos.cetesb.sp.gov.br/wp-content/ uploads/sites/36/2013/11/inventario-RSD-2015.pdf (accessed 3 February 2017).

Dias SM (2011) Statistics on waste pickers in Brazil. WIEGO Statistics Brief 2. Available at: http://wiego.org/sites/wiego.org/files/publications/files/ Dias_WIEGO_SB2.pdf (accessed 3 September 2015).

DRZ Geotecnologia e Consultoria S/S LTDA (2015) Meta é 100\% de Coleta Seletiva até 2035. Sorocaba, 6 abr. 2015. Available at: http://www.drz. com.br/noticia.php?n=597\&noticia=Meta_e_100_de_coleta_seletiva_ ate 2035 (accessed 23 October 2015).

Eigenheer EM (2009) A limpeza urbana através dos tempos. Porto Alegre: Gráfica Pallotti. Available at: http://www.lixoeeducacao.uerj.br/imagens/ pdf/ahistoriadolixo.pdf (accessed 15 August 2015).

Ezeah C, Fazakerley JA and Roberts CL (2013) Emerging trends in informal sector recycling in developing and transition countries. Waste Management 33: 2509-2519.

Franceschini G, Ribeiro CL and Machado MLT (2010) Economia Solidária e Autonomia Social: Contribuições do Trabalho dos Catadores/as de Resíduos para a Sustentabilidade Socioambiental. In: Proceedings of the $V$ Encontro Nacional da ANPPAS, Florianópolis, Brazil, 4-7 October, pp.1-16.

FUNASA (Fundação Nacional da Saúde) (2010) Programas Municipais de Coleta Seletiva de Lixo como Fator de Sustentabilidade dos Sistemas Públicos de Saneamento Ambiental na Região Metropolitana de São Paulo. Brasília, Brazil: FUNASA, 170 pages.

Furlan W (2007) Modelo de Decisão para Escolha de Tecnologia para o Tratamento de Resíduos Sólidos no Âmbito de um Município. Master Thesis, University of São Paulo, Brazil.

GIZ (Deutsche Gesellschaft Für Internationale Zusammenarbeit) (2011) Recovering Resources, Creating Opportunities: Integrating the Informal Sector into Solid Waste Management. Eschborn, Germany: Aksoy Print. 
Grimberg E (2007) Coleta seletiva com inclusão social: Fórum Lixo e Cidadania na Cidade de São Paulo. Experiência e desafios. São Paulo, Brazil: Instituto Pólis.

IBGE (Instituto Brasileiro de Geografia e Estatísticas) (2010) Censo Demográfico 2010. Available at: http://cidades.ibge.gov.br/xtras/temas.php ?lang $=\&$ codmun $=355220 \&$ idtema $=1 \&$ search $=$ sao-paulo $\mid$ sorocaba $\mid$ censodemografico-2010:-sinopse- (accessed 4 July 2015).

IBGE (Instituto Brasileiro de Geografia e Estatísticas) (2013a) Cidades, São Paulo, Sorocaba. Available at: http://cidades.ibge.gov.br/xtras/ perfil.php?lang=\&codmun $=355220 \&$ search $=\|$ infogr $\%$ E 1 ficos :informa $\%$ E7\%F5es-completas (accessed 20 September 2015).

IBGE (Instituto Brasileiro de Geografia e Estatísticas) (2013b). Síntese de Indicadores Sociais: Uma Análise das Condições de Vida da População Brasileira. Available from: ftp://ftp.ibge.gov.br/Indicadores_Sociais/ Sintese...2013/SIS_2013.pdf (accessed 5 July 2015).

INSEA (Instituto Nenuca de Desenvolvimento Sustentável) (2013) Prestação de Serviços de Coleta Seletiva por Empreendimentos de Catadores: Instrumentos Metodológicos para Contratação. Belo Horizonte, Brazil: INSEA, 110 pages.

IPEA (Instituto de Pesquisa Econômica Aplicada) (2010) Relatório de Pesquisa: Pesquisa sobre Pagamento por Serviços Ambientais Urbanos para Gestão de Resíduos Sólidos. Diretoria de Estudos e Políticas Regionais, Urbanas e Ambientais. Brasília, Brazil. Available at: http:// www.mma.gov.br/estruturas/253/_arquivos/estudo_do_ipea_253.pdf (accessed 23 September 2015).

IPEA (Instituto de Pesquisa Econômica Aplicada) (2013) Situação Social das Catadoras e dos Catadores de Material Reciclável e Reutilizável. Brasília, Brazil: IPEA, 40 pages.

Jacobi PR and Besen GR (2011) Solid waste management in São Paulo: The challenges of sustainability. Estudos Avançados 25: 135-158.

Lindeman S (2012) Market formation in subsistence contexts: a study of informal trade practises in Tanzania and Brazil. Consumption Markets \& Culture 15: 235-257.

Lopes L (2006) Gestão e Gerenciamento Integrados dos Resíduos Sólidos Urbanos: Alternativas para Pequenos Municipios. Master Thesis, University of São Paulo, Brazil.

Lükte E (2013) Recyclers in Brazil - From Risk to Empowerment. Essay for Master in Global Studies. Gothenburg University, Sweden, pp. 20.

Mancini SD (2015) O vai e vem do lixo. Jornal Cruzeiro do Sul, Sorocaba, 4 ago. 2015. Available at: http://www.jornalcruzeiro.com. br/materia/629334/o-vai-e-vem-do-lixo (accessed 10 November 2015).

Mantovani VA, Mancini SD, Barros TR, et al. (2016) Evaluation and quantification of household wastes sent for recycling through a selective waste collection system. Journal of Solid Waste Technology and Management 42: 116-128.

Marques MIM (2013) O Trabalho dos Catadores de Resíduos Sólidos na Metrópole Paulistana em Tempos de Políticas Neoliberais. Reciclagem e Gestão do Ambiente Urbano, pp.76-89.

MMA - Ministério do Meio Ambiente (2010) Manual para Implantação de Compostagem e de Coleta Seletiva no Âmbito de Consórcios Públicos. Brasilia, Brazil: MMA.

MNCR - Movimento Nacional de Catadores de Materiais Recicláveis (2008) Ciclo da Cadeia Produtiva de Reciclagem. Available at: http://www. mncr.org.br/box_4/formacao-e-conjuntura/ciclo-da-cadeia-produtiva-dereciclagem (accessed 7 July 2015).

Pinheiro LR, Amaral MF, Lisboa CP, et al. (2014) Sujeitos, Políticas e Educação Ambiental na Gestão de Resíduos Sólidos. Educação \& Realidade 39: 535-556.

Pinheiro Pedro F, Denny D, Fiorini K, et al. (2012) The new waste policy in Brazil under the social inclusion perspective. In: Proceedings of the
International solid waste association world congress 2012, Florence, Italy, 17-19 September, pp. 1-7.

PMS - Prefeitura Municipal de Sorocaba \& SHS Consultoria e Projetos de Engenharia LTDA. (2014) Plano Municipal de Gestão Integrada de Resíduos Sólidos de Sorocaba. Available at: http://www.sorocaba. sp.gov.br/portal/sem-categoria/plano-municipal-de-residuos (accessed 30 September 2015).

PMS - Prefeitura Municipal de Sorocaba \& DRZ Geotecnologia e Consultoria S/S LTDA. (2015) Plano Municipal de Coleta Seletiva. Available at: http://www.sorocaba.sp.gov.br/portal/servicos/plano-municipal-decoleta-seletiva (accessed 5 October 2015).

Programa Catação \& Instituto Walmart (2013) Inspiração: Relatos, Experiências e Boas Práticas de três iniciativas de Catadores. Available at: http://www. avina.net/por/wpcontent/uploads/2013/08/969_PublicaAAoInspiraAAopdf. pdf (accessed 5 August 2015).

Rede Nossa São Paulo (2013) Guia para a implantação da Política Nacional de Resíduos Sólidos nos municípios brasileiros de forma efetiva e inclusiva. São Paulo, Brazil.

Rutkowski JE, Lima FPA and Oliveira FG (2013) Aprimoramento da Gestão de Resíduos Sólidos Urbanos por meio do Incentivo à Reciclagem: Uma Metodologia para Cidades Mais Sustentáveis. In: Proceedings of the III Conferência Internacional de Gestão de Resíduos Sólidos, São Paulo, Brazil, 4-6 September, pp.1-10.

Rutkowski JE and Rutkowski EW (2015) Expanding worldwide urban solid waste recycling: The Brazilian social technology in waste pickers inclusion. Waste Management \& Research 33:1084-1093.

SANEX Soluções LTDA (2011) Avaliação, Diagnóstico e Proposição de Soluções visando a elaboração do Plano Municipal de Resíduos Inertes e Recicláveis do Município de Sorocaba. Sorocaba: SANEX.

Scheinberg A (2012) Informal sector integration and high performance recycling: Evidence from 20 cities. WIEGO Working Paper 23.

Simões GVB, Ferraz JL, Mancini SD, et al. (2011) Coleta Seletiva como Instrumento de Políticas Públicas: a Experiência do Município de Sorocaba-SP. In: 3rd international workshop - advances in cleaner production, Sao Paulo. Available at: http://www.advancesincleanerproduction.net/third/files/sessoes/5B/6/Simoes_GVB\%20-\%20Paper\%20-\%20 5B6.pdf (accessed 8 October 2015).

Simões GVB (2012) Programa de Coleta Seletiva de Sorocaba. Sorocaba: Secretaria de Parcerias.

SNIS - SISTEMA NACIONAL DE INFORMAÇÕES SOBRE SANEMENTO (2014) Diagnóstico do Manejo de Resíduos Sólidos Urbanos - 2012. Brasília, Brazil: Ministério das Cidades.

Spinosa CMC (2012) Políticas Públicas Direcionadas a Coleta Seletiva no Município de Sorocaba - SP. Bachelor Thesis, Federal Tecnology University of Paraná. Available at: http://repositorio.roca.utfpr.edu. br/jspui/bitstream/1/1806/1/CT_GPM_II_2012_69.pdf (accessed 5 September 2015).

Velis CA, Wilson DC, Rocca O, et al. (2012) An analytical framework and tool ('InteRa') for integrating the informal recycling sector in waste and resource management systems in developing countries. Waste Management \& Research 30: 43-66.

Viana RCG (2012) Rede Solidária Cata-Vida: construindo a sustentabilidade dos empreendimentos econômicos solidários dos catadores de materiais recicláveis na região de Sorocaba/SP. Inclusão Social 6: 78-83.

Wilson DC, Velis C and Cheeseman C (2006) Role of informal sector recycling in waste management in developing countries. Habitat International 30: 797-808.

Wilson DC and Velis C (2014) Cities and waste: current and emerging issues. Waste Management \& Research 32: 797-799. 